\title{
Article \\ Analysis of Fault Conditions in the Production of Prestressed Concrete Sleepers
}

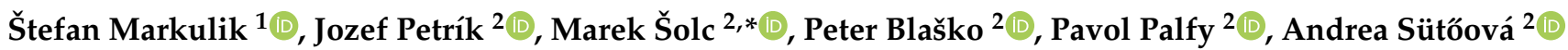 \\ and Lenka Girmanová ${ }^{2}$ (I)
}

1 Department of Safety and Quality, Faculty of Mechanical Engineering, Technical University of Kosice, Letna 1/9, 04200 Kosice, Slovakia; stefan.markulik@tuke.sk

2 Faculty of Materials, Metallurgy and Recycling, Institute of Materials and Quality Engineering, Technical University of Kosice, Letna 1/9, 04200 Kosice, Slovakia; jozef.petrik@tuke.sk (J.P.); peter.blasko@tuke.sk (P.B.); pavol.palfy@tuke.sk (P.P.); andrea.sutoova@tuke.sk (A.S.); lenka.girmanova@tuke.sk (L.G.)

* Correspondence: Marek.Solc@tuke.sk; Tel.: +421-55-602-2703

check for updates

Citation: Markulik, Š.; Petrík, J.; Šolc, M.; Blaško, P.; Palfy, P.; Sütőová, A.; Girmanová, L. Analysis of Fault Conditions in the Production of Prestressed Concrete Sleepers. Appl. Sci. 2022, 12, 928. https://doi.org/ 10.3390/app12020928

Academic Editor: Doo-Yeol Yoo

Received: 19 November 2021

Accepted: 14 January 2022

Published: 17 January 2022

Publisher's Note: MDPI stays neutral with regard to jurisdictional claims in published maps and institutional affiliations.

Copyright: (C) 2022 by the authors. Licensee MDPI, Basel, Switzerland. This article is an open access article distributed under the terms and conditions of the Creative Commons Attribution (CC BY) license (https:// creativecommons.org/licenses/by/ $4.0 /)$.

\begin{abstract}
Industries demand that their products are high quality with the least number of defects due to the rapid improvement in manufacturing technology. Quality is a critical criterion for evaluation in manufacturing firms. The production of a final product that can meet customer requirements is essential in a sustainable supply chain system to reduce costs, increase productivity and provide high-quality products. The aim of the study is to identify the root cause of defects emerging in the production process of prestressed railway concrete sleepers. Ishikawa diagram and Pareto analysis were used to identify the root cause. The results showed that the cause of the faulty concrete sleeper is the breaking of the bolts, which are supplied by the external provider. Since the supplier refused to accept the complaint, chemical analysis and measuring of hardness and microhardness of bolts were realized. It showed that the hardness of the bolts does not achieve the values, which should be achieved after the declared heat-treatment. As a corrective action, the input control of bolts hardness was proposed as well as establishing the team cooperating with the supplier to improve the heat treatment process, which will be the objective of further study.
\end{abstract}

Keywords: prestressed concrete sleeper; nonconforming product; Ishikawa diagram; Pareto diagram; metallography; hardness

\section{Introduction}

The biggest challenge facing today's manufacturing companies is to reduce production costs while still maintaining good quality and high productivity [1,2]. Quality has always been an essential part of manufacturing.

The quality of products is critical to satisfying customers and retaining their loyalty. According to the ISO 9000:2015, quality is defined as a degree to which a set of inherent characteristics of an object fulfills requirements [3,4]. It is important to consider legal and customer requirements, which both input into the quality management system of an organization. In terms of legal requirements on construction products, it is worth mentioning the Regulation of EU No. 305/2011 that lays down harmonized conditions for the marketing of construction products [5]. Products of high quality which meet customer requirements and needs positively affect an organization's revenue and profit whereas poor quality increases an organization's costs associated with repairs, scraps, sanctions, or even loss of customers [6-9]. The quality of input significantly affects the effectiveness of organization processes and the quality of final products. Supplier quality is a supplier's ability to deliver products or services that will satisfy customers' requirements and needs [10]. The quality of supplies is often accomplished through the use of supplier quality management, which allows companies to monitor supply chains and inspect products at regular intervals. Supply 
chain quality management is a systems-based approach to performance improvement that leverages opportunities created by upstream and downstream linkages with suppliers and customers [11]. The ISO 9001 quality management system standard contains requirements for the determination and application of criteria for evaluation, selection and monitoring of supplier' performance [12]. Certified suppliers and long-term relationships can positively affect quality and supply chain initiatives. Constantly changing suppliers, merely due to price, increases the variation in the materials and delivery time [13]. Poor quality of input materials and products is reflected in the production processes of the organization and results in defective finished products. The quality deficiencies of input materials and products can even pose potential safety risks [14-16].

Companies have always focused on methods and techniques to improve and manage quality, even in the past. The root cause analysis is a process for identifying the basic or causal factors that underlie a variation in performance and facilitating corrective actions to prevent reoccurrence [17-19]. The root cause analysis is part of a more general problem-solving process and an integral part of continuous improvement [20]. It helps to describe what happened during a particular incident, to determine how it happened, and to understand why it happened. According to [21], the causes can be classified as: 1. Symptoms - these are not regarded as actual causes but rather signs of existing problem; 2. first level causes - causes that directly lead to problems; 3. higher-level causes_causes that lead to a first level causes, not directly cause the problem [22]. The highest level causing the problem is the root cause. Tools that assist groups or individuals in identifying the root causes of problems are known as root cause analysis tools. There are several tools that can be used e.g., 7 basic and seven advanced quality tools, 5 Why, Cross Assembling, Is-Is Not Analysis, Following Lines of Evidence, Parameter Diagram, Boundary Diagram, $8 \mathrm{D}$ Report, etc. The literature sources confirm that the mentioned tools have the capacity to find the root causes with varying degrees of accuracy, efficiency, and quality [23]. The root cause analysis has been extensively used in various industries especially in the machinery industry, e.g., [24-27]. However, there are few studies of this approach being used in construction e.g., [28-31].

The paper deals with the analysis of root causes of nonconforming products occurring in the production process of railway prestressed concrete sleepers, while Ishikawa Diagram and Pareto analysis were applied. In order to achieve the goal of the study, the measuring of mechanical properties and structural analysis were also carried out. The study contributes to the existing body of knowledge in the practical application of the selected tools of root cause analysis in the construction industry.

\section{Characteristics of the Manufacturing Process of Prestressed Railway Concrete Sleepers in the Context of the Failure Causes}

The organization, whose main item in the product range are railway sleepers, believes that it will produce the required number of sleepers from the supplied raw materials-concrete, reinforcements, energy, meeting the requirements of the customer, and standards. If a sleeper is produced, which does not meet these requirements, it is irreparable, i.e., it represents a loss, and it also incurs disposal costs as unwanted waste. The same applies if the sleeper is not finalized, for example for premature leakage of uncured concrete from the mold. Based on a long-term analysis of the quality control of the production process, the organization found an increase in non-conformities. If, on a monthly basis, the organization records an increase in the number of nonconforming products above the permitted $2 \%$, it will analyze the causes and then take corrective action.

The load-bearing structure of the sleeper and its durability depend on two basic elements: the concrete used and the prestressing of the reinforcement. The concrete should have enough compressive and tensile strength. Prestressing of the steel reinforcement will increase the durability of the sleepers, especially in terms of material fatigue, as there is no alternation of tension and pressure under load. 
The sleepers in question are made of $C 45 / 55$ cement. They must meet the requirements of the standards EN 13230-1, 2: 2016 [32,33].

The production of concrete sleepers takes place on a semi-automated production line, and it is a serial production, where the individual workplaces follow each other, and therefore every activity is very important for the production of a quality product.

\section{Sleeper Production Process}

1. The sleeper mold is loaded on a rail conveyor, cleaned of any dirt and concrete residues, and a separation emulsion is applied to its walls. In 1 mold, $4-5$ sleepers are produced, depending on the length of the sleeper;

2. Steel wires, stirrups, dowels, separating faces, and other equipment elements are placed in the mold. The longitudinal reinforcement consists of 40 wires with a diameter of $3 \mathrm{~mm}$, which are separated and held by the jaws. The $8 \times 5$ matrix consists of 8 wires in each row. The jaws are tightened with two flanges, using two bolts. The bolts are tightened using a pneumatic tightener with a prescribed torque of $23 \mathrm{Nm}$. In the first step, the bolts on one side of the mold are tightened and after tensioning the reinforcement, the bolts on the other side of the mold are tightened. The range of tests for prestressing reinforcement is specified in the standard PrEN 10138-2 [34];

3. The reinforcement is prestressed by a tension line to the prescribed value. The magnitude of the tensile force is recorded. Prestressed steel reinforcement must comply with the requirements of PrEN 10138-2, steel for other reinforcements must comply with EN 10080 [35];

4. The produced concrete mix is dosed into the mold and then compacted vibrating the whole mold for the prescribed time. The concrete must meet the requirements of EN 206-01 [36] and EN 13230-1 [32], it must also meet the requirements for frost resistance T 200 according to STN 731322 [37]. The temperature of the cement when dosing into the mixer must not exceed $60^{\circ} \mathrm{C}$. The quality of the aggregate must comply with the requirements of EN 12620 + A1: 2008-12 [38];

5. At the workstation for accelerating the hardening (hydration) of sleepers, the molds are transferred by crane from a rail conveyor into a steaming chamber with a capacity of 100 molds. The steaming process takes about $12 \mathrm{~h}$. The tests must show the actual temperatures inside and around the sleeper. The temperature profile is recorded and should not exceed $45^{\circ} \mathrm{C}$.

At the cutting and stacking workstation, the molds are overturned and the sleepers are pushed onto a conveyor, where they are separated. Subsequently, the surface and appearance of the product will be inspected. The surface of the sleeper must be well filled out. Isolated cavities with a closed surface up to $100 \mathrm{~mm}^{2}$ and a depth up to $5 \mathrm{~mm}$ are permitted. Fragments on edges and surfaces are not permitted in places where they could interfere with the fastening function. The load-bearing surface of the sleeper (the surface that is in contact with the fastening) must be undamaged. The reinforcement must not protrude more than $8 \mathrm{~mm}$ from the sleeper front. The absence of longitudinal wire from the reinforcement or twisting of the wires is not allowed. The sleeper mold and failure point are shown in the Figure 1. 

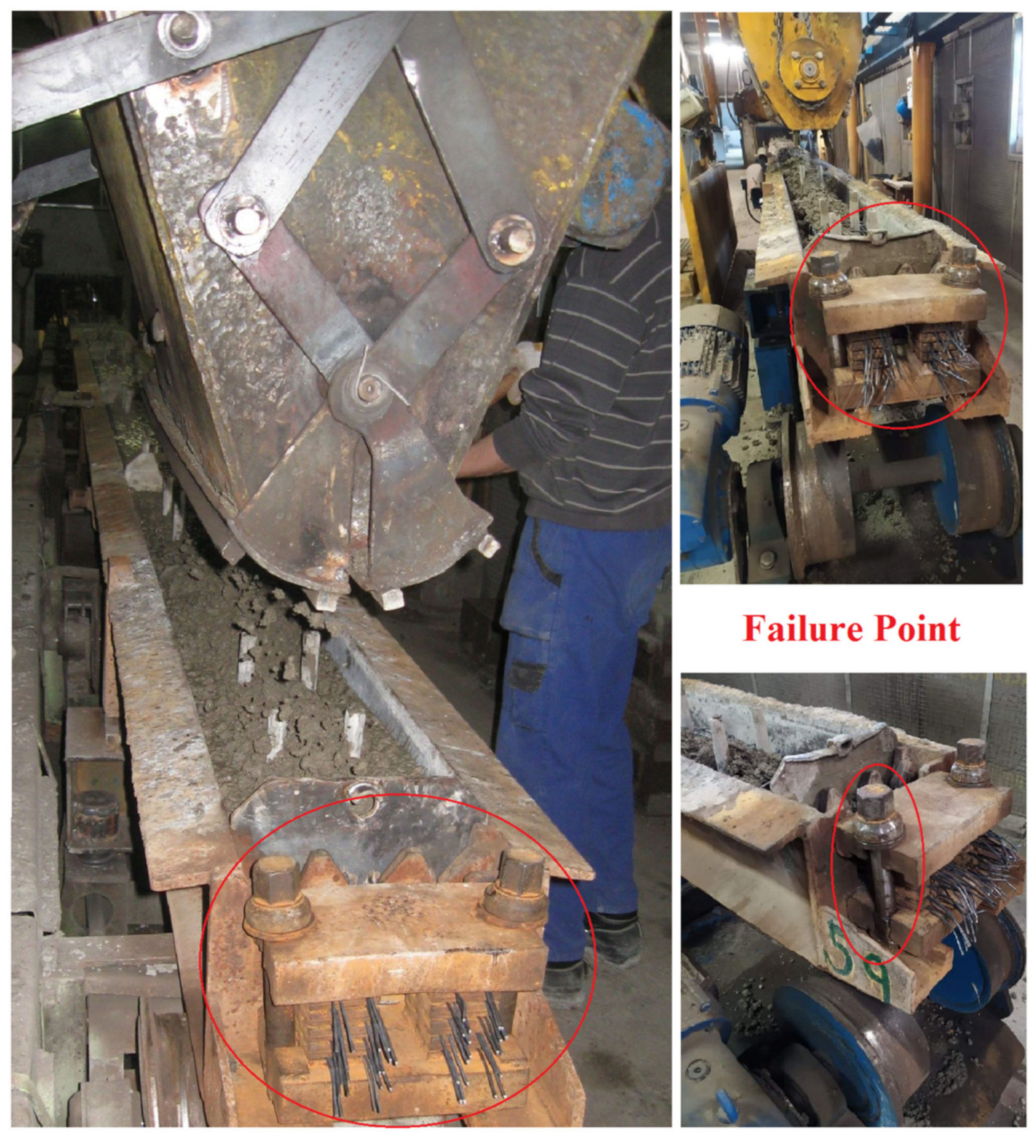

Failure Point

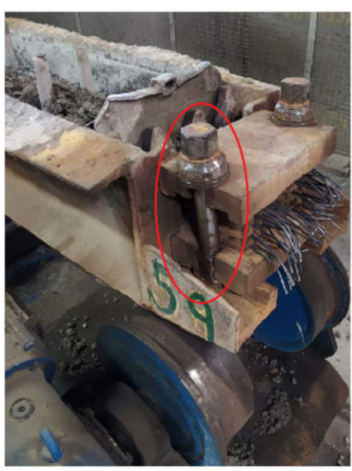

Figure 1. The sleeper mold and the failure point.

\section{Methods}

In the first approach, two selected basic quality tools were used to analyze the problem: Ishikawa diagram, Pareto diagram. We then used chemical analysis, microhardness and macrohardness measurement, as well as structural analysis.

Many authors, for example Girmanová et al. [39], recommend constructing a causeand-effect diagram, also called Ishikawa diagram after its creator. It allows for a "clarification" of the problem and is often used to identify the sources that contribute to the analyzed problem and the relationships between them [20,40].

The diagram is a visualization tool for categorizing the potential causes of the problem, the top event, in order to identify its basic or root causes. The head and backbone of the fish represent the top event-the problem or issue to be studied. Six "causes" that contribute to the problem (Materials, Machines, Manpower, Methods, Measurement, Environment) create the first bones (ribs) of the fish. Other, more specific levels of bones (horizontal, vertical, horizontal ... ) can be added to the "ribs" until the cause of the problem can be divided into subcategories. The practical number of levels is usually from 4 to 5 . The lowest level is a basic event. A correctly designed diagram significantly facilitates the design of Pareto analysis [41].

A Pareto chart is a bar graph. The lengths of the bars represent frequency or cost (time or money) and are arranged with the longest bars on the left and the shortest to the right. In this way, the chart visually depicts which situations are more significant [42].

After specifying the possible causes of failures, it was necessary to proceed to the chemical analysis, which was performed with a Niton XL3 Goldd spectrometer on metallographic specimens. The analysis was performed at two sites of the sample. The spectrometer used does not allow for a determination of the carbon content. The chemical analysis was followed by the determination of mechanical properties. Regarding the dimensions of the samples, the determination of microhardness and macrohardness was 
used. Finally, the same samples were used for structure analysis. Samples for hardness measurement and structure analysis were taken about $10 \mathrm{~mm}$ below the point of failure by parting on the lathe under intense cooling.

After separation, the samples were cast in resin (dentacryl) and successively sanded on sandpapers 120 to 3000 ANSI/CAMI with intense water cooling. They were then polished with an aqueous suspension of spinelin $\left(\mathrm{Al}_{2} \mathrm{O}_{3}\right)$. The sample was observed in an unetched state (for the occurrence of possible cracks, inclusions, etc.) and was subsequently etched with $2 \%$ nital. Reflected light microscopic analysis was performed on a Neophot 32 optical microscope. The phase fraction was determined with ImageJ software.

Macrohardness was measured with a universal hardness tester HPO 250 by the Brinell method (HBW 2.5/187.5/15). The hardness tester has been calibrated before use and meets the requirements of ISO 6506-2: 2017 [43]. Macrohardness was measured according to ISO 6506-1: 2014 [44] on metallographic specimens and for sample 1 also at the bottom of the sample (extended lower part of the bolt). The relative expanded uncertainty $U_{\text {rel }}(k=2)$ of the measured values was calculated according to the same standard ISO 6506-1: 2014 [44].

Microhardness was measured by the Vickers method with a Hanemann hardness tester in a Neophot 32 microscope with a magnification of $480 \times$. Discriminant-the value of the smallest division of the optical device of the microhardness tester measuring the diagonals of the impressions is $0.000313 \mathrm{~mm}$. This is from 1.1 to $3.1 \%$ of the average diagonal length depending on the load used. A hardness tester plate (CRM, certified reference material) with a specific hardness Hc $=195$ HV0.05 and a standard uncertainty of $u=4.0$ HV0.05 was used to calibrate the hardness tester. The hardness tester meets the requirements of ISO 6507-2: 2018 [45].

The same operator measured the microhardness of selected areas on metallographic specimens according to ISO 6507-1: 2018 [46]. The applied loads were $0.09807 \mathrm{~N}$ (10 g), $0.24518 \mathrm{~N}(25 \mathrm{~g}), 0.49035 \mathrm{~N}(50 \mathrm{~g})$ and $0.9807 \mathrm{~N}(100 \mathrm{~g})$. The loading time was $15 \mathrm{~s}$. The relative expanded uncertainty $\mathrm{U}_{\text {rel }}(\mathrm{k}=2)$ of the measured values was calculated according to the same ISO 6507-1: 2018 standard [46].

\section{The Results}

As can be seen in Figure 2, the ribs have been modified according to actual problems of the process of sleeper production (Measurement, Materials, Methods, Environment, Manpower, Machine). The whole diagram was not used to construct the Pareto diagram; rather, only the most numerous, and especially measurable, causes were taken into account.

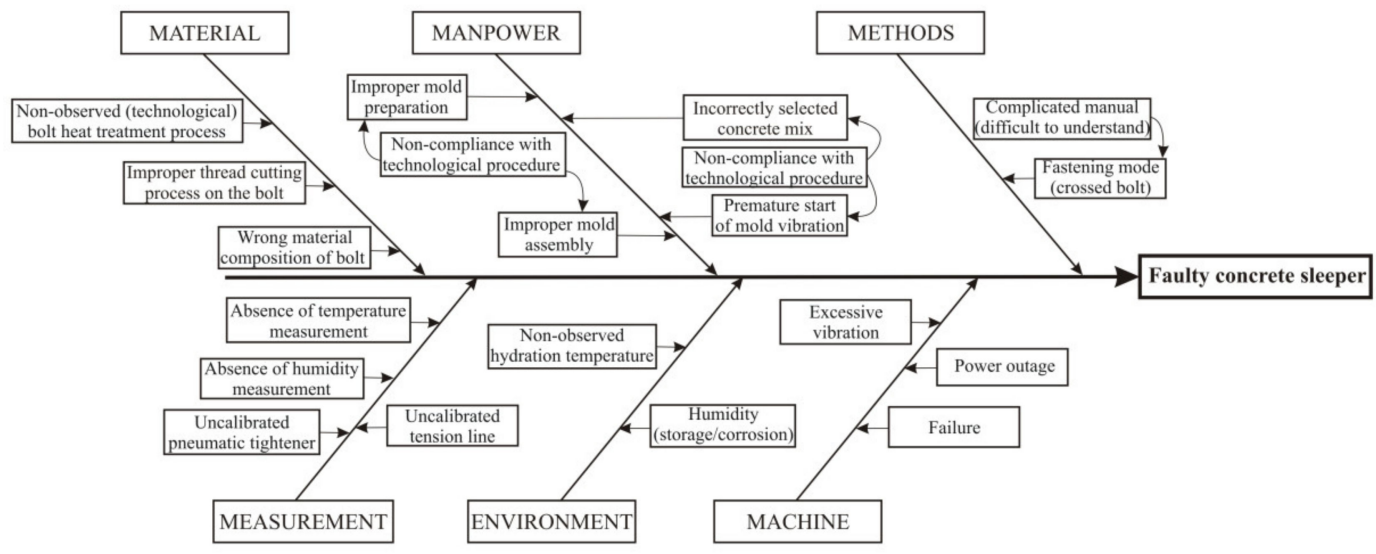

Figure 2. Ishikawa diagram.

\section{Problem Statement: Faulty Concrete Sleeper}

Regarding the "Measurement" rib, three possible causes of non-conformity in the final product were identified, namely the absence of temperature and humidity gauges, an uncalibrated pneumatic bolt tightener and an uncalibrated steel reinforcement tension line. Inaccurate torque settings of the tightening bolts can reduce their service life or cause 
them to crack. The same applies to the tension line, where the prescribed arrangement of the steel wires may not be ensured at a low tension, while the wires may crack at high tension. The root cause for this rib is the absence of a measurement management system in the organization.

Three possible causes have been identified in the "Materials" rib: incorrect bolt material composition, non-compliant bolt heat treatment process or improper bolt cutting process. These causes are virtually unaffected by the organization. They concern only the supplier. The organization does not carry out an entry checks of bolts, rather it has been relying on the supplier's certificate.

One possible cause was identified in the "Methods" rib: the method of fixing the steel reinforcement (improperly fitted wires, flanges, jaws, cross bolt). The manual is confusing, voluminous, and difficult to understand.

The "Manpower" rib is extremely important because the factors involved influence other ribs as well. The operator that forms its core is involved in what is happening in the other ribs and thus in the causes they contain. Three causes were identified in this rib: non-compliance with technological process (incorrect mold preparation, imperfect mold cleaning, imperfectly applied separation emulsion), incorrect mold furnishing (incorrect steel reinforcement preparation, improperly selected steel reinforcement preload, nonobserved prescribed moment in bolt tightening process), the premature start of mold vibration could be a problem due to the segregation of concrete mix components and loosening or snapping of wires, improperly selected concrete mixture. Cracking and subsequent ejection of parts of bolts causes security threats where the operator may be injured or disturbed. An anxious operator is more prone to making a mistake.

Two causes have been identified in the "Machine" rib, namely excessive vibration and power outage or failure.

The "Environment" rib has two possible causes: non-compliance with the hydration temperature, non-compliance with the humidity in the warehouse (bolts, fronts, reinforcement elements) are exposed to corrosion.

During 1 8-h shift, 300-350 pieces of sleepers are produced, depending on their length, 4 or 5 sleepers are produced in 1 mold. The service life of the bolts is half a year in two-shift operation, during which the bolt is used about 240 times. Data obtained for the month of April 2021 were used for statistical analysis, after the production of 14,081 sleepers, of which 301 were defective, or an error occurred in the production process that prevented its finalization.

Based on the Ishikawa diagram and statistical analysis of nonconforming products listed in Table 1, a Pareto diagram, Figure 3, was constructed.

Table 1. Causes of faulty concrete sleeper.

\begin{tabular}{cc}
\hline Causes of Faulty Concrete Sleeper & Total (\%) \\
\hline Fractured bolt & 41 \\
\hline Fragments on the sleeper & 24 \\
\hline The steel reinforcement defect & 15 \\
\hline Loosening of the dowel & 8 \\
\hline Front face concrete overflow & 7 \\
\hline Unsuitable concrete mixture & 3 \\
\hline Power outage/failure & 2 \\
\hline
\end{tabular}




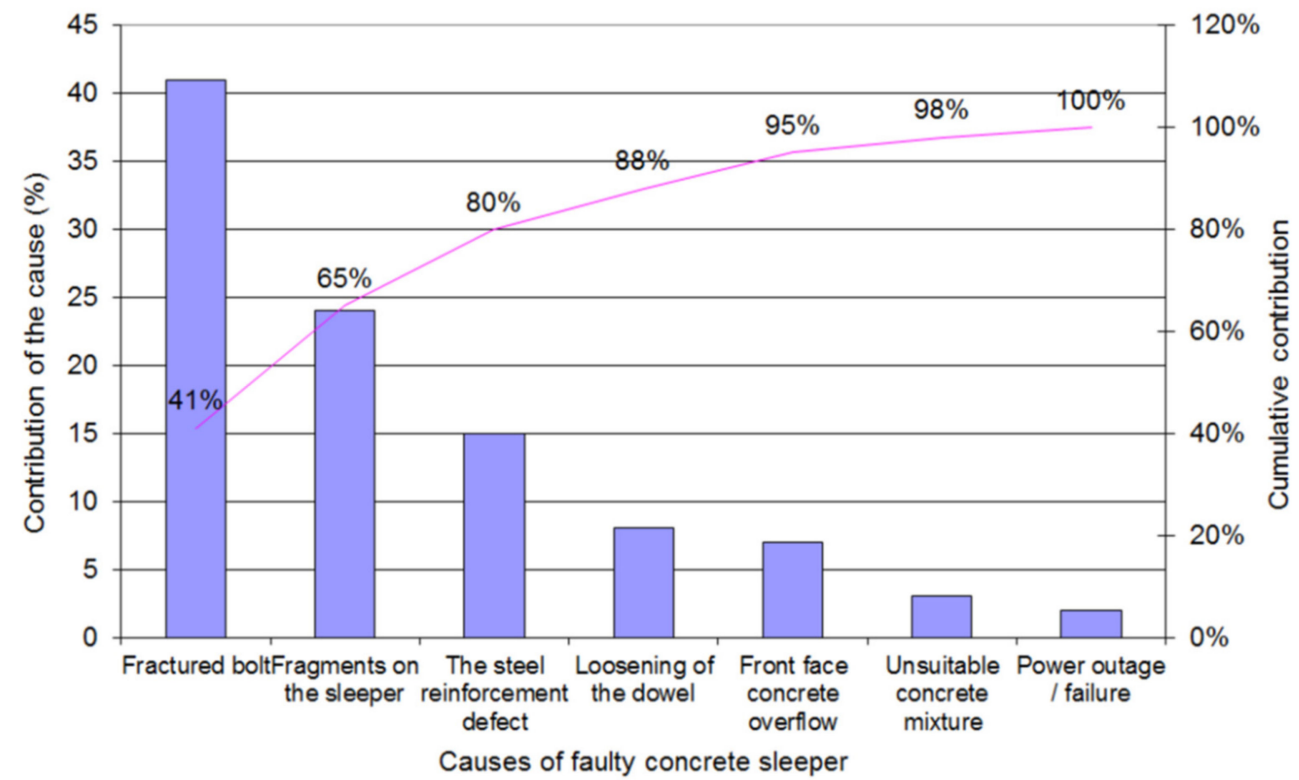

Figure 3. Pareto diagram-contribution of causes of faulty concrete sleepers.

It is clear from the diagram that the most significant source of the cause of the faulty concrete sleeper is the breakage (cracking) of the bolts that hold the prestressed steel reinforcement. As the visual inspection of the construction parameters (dimensions, surface, thread geometry...) of the bolt corresponds to the requirement, the research was further focused on material analysis, i.e., whether the material, mechanical properties and structure meet the customer's requirements and the relevant technical standard.

A total of 2 prematurely cracked bolts (No. 1 and No. 2) were manufactured by an external supplier. According to the agreement, carbon steel STN 12061 (corresponding to EN ISO C60E) was to be used. The standardized composition of these steels is in Table 2. The organization trusted the supplier's data, did not perform any inspection of the production process or any acceptance inspection of the bolts.

Table 2. The standard composition of steels according to STN 12061 and EN ISO: C60E.

\begin{tabular}{cccccccc}
\hline & C (\%wt) & Mn (\%wt) & Si (\%wt) & Cr (\%wt) & Mo (\%wt) & Ni (\%wt) & Cu (\%wt) \\
\hline STN 12 061 & $0.57-0.65$ & $0.5-0.8$ & $0.17-0.37$ & 0.25 & & 0.3 & 0.3 \\
\hline EN ISO: C60E & $0.57-0.65$ & $0.6-0.9$ & $<0.4$ & $<0.4$ & $<0.1$ & $<0.4$ & \\
\hline
\end{tabular}

A possible cause of premature bolt cracking is material substitution. Therefore, chemical analysis was performed with a Niton XL3 Goldd spectrometer. If we compare the results of the analysis given in Table 3 with the standardized composition given in Table 2, it is clear that there was no substitution of material.

Table 3. Informative chemical analysis.

\begin{tabular}{cccccccccccc}
\hline Sample & Fe & Si & Mn & Cr & Mo & Ni & Sn & Cu & S & P \\
\hline 1 & 97.414 & 0.283 & 0.908 & 0.069 & 0.017 & 0.108 & 0.016 & 0.229 & $<$ LOD & 0.043 \\
\hline 1 & 97.597 & 0.269 & 0.921 & 0.064 & 0.018 & 0.103 & 0.018 & 0.242 & $<$ LOD & 0.056 \\
\hline 2 & 97.455 & 0.345 & 0.807 & 0.079 & 0.019 & 0.128 & 0.017 & 0.215 & $<$ LOD & 0.041 \\
\hline 2 & 97.49 & 0.351 & 0.809 & 0.072 & 0.019 & 0.125 & 0.016 & 0.232 & $<$ LOD & 0.047 \\
\hline
\end{tabular}

Whether the bolts met the requirements for mechanical properties was determined by measuring hardness and microhardness. It is a relatively fast, simple, and non-destructive 
method. It was also chosen because the relevant standard specifies hardness values, and other tests (e.g., uniaxial tensile test) of mechanical properties are complicated.

The hardness and microhardness of samples No. 1 a No. 2 are given in Table 4 . They correspond to the values of hardness in the annealed state (e.g., 241 HBW after soft annealing) but not the hardness after the declared heat treatment (e.g., 345-530 HV in quenched and tempered state). Low hardness values suggest that the heat treatment has not been correctly conducted or has not been applied at all. This led to the analysis of the structure of the bolt material.

Table 4. Hardness and Microhardness.

\begin{tabular}{|c|c|c|c|c|c|c|c|c|c|c|}
\hline \multirow{2}{*}{$\begin{array}{l}\text { Sample } \\
\text { No. }\end{array}$} & \multicolumn{2}{|c|}{$\begin{array}{c}\text { Hardness } \\
\text { Metallografic } \\
\text { Surface }\end{array}$} & \multicolumn{2}{|c|}{$\begin{array}{l}\text { Hardness, Bottom } \\
\text { Part of the Bolt }\end{array}$} & \multicolumn{5}{|c|}{$\begin{array}{c}\text { Microhardness of the Grains, Metallografic } \\
\text { Surface }\end{array}$} & \multirow{2}{*}{$\begin{array}{c}\begin{array}{c}\text { Microhardness } \\
\text { of Ferrite } \\
\text { Metallografic } \\
\text { Surface }\end{array} \\
\text { HV0.01 }\end{array}$} \\
\hline & HBW & $\mathrm{U}_{\text {rel }}(\%)$ & HBW & $\mathrm{U}_{\text {rel }}(\%)$ & HV0.01 & HV0.025 & HV0.05 & HV0.1 & $\overline{H V}$ & \\
\hline 1 & 243 & 3.47 & 250 & 4.29 & 203 & 231 & 200 & 228 & 216 & 193 \\
\hline 2 & 256 & 3.08 & - & - & 160 & 256 & 236 & 247 & 245 & 149 \\
\hline
\end{tabular}

Structural analysis showed that sample no. 1 is formed by lamellar perlite grains with a diameter of 50 to $130 \mu \mathrm{m}$, lined with ferrite, Figure 4 (nital, $250 \times$ ). The proportion of ferrite is $13.7 \%$, the thickness of ferritic envelopes is $2-26 \mu \mathrm{m}$. Sample No. 2 has a similar microstructure, but with a lower proportion of ferrite $(7.15 \%)$, Figure 5 (nital, $250 \times)$. The differences in microhardness are due to the different density of pearlitic lamellae. The microstructure of both samples indicated that they were not heat treated, and if so, then the heat treatment was only "formal" - the austenitization annealing temperature was low or the annealing time was too short, in both cases insufficient for visible changes in the microstructure. The third option would be sufficient austenitization, after which there was no hardening, but only slow cooling. The result is the presence of ferrite and low hardness, which is the cause of insufficient strength properties of bolts and their premature fracture.

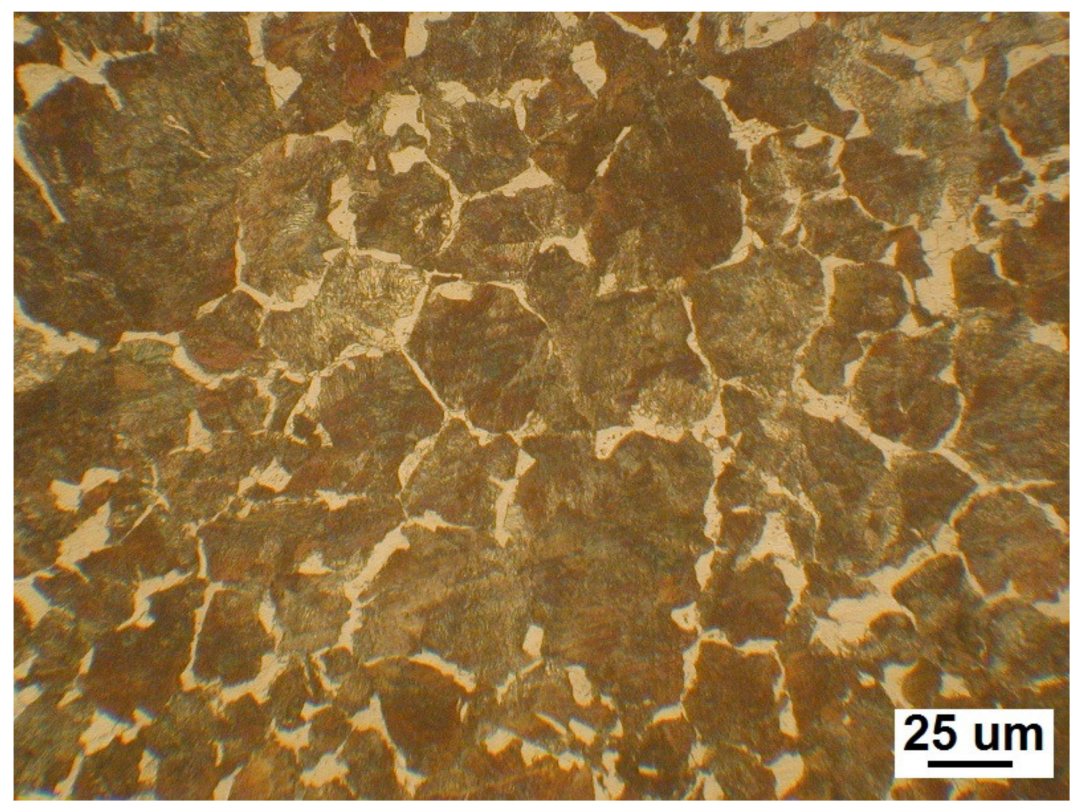

Figure 4. Sample No. 1, microstructure (nital). 


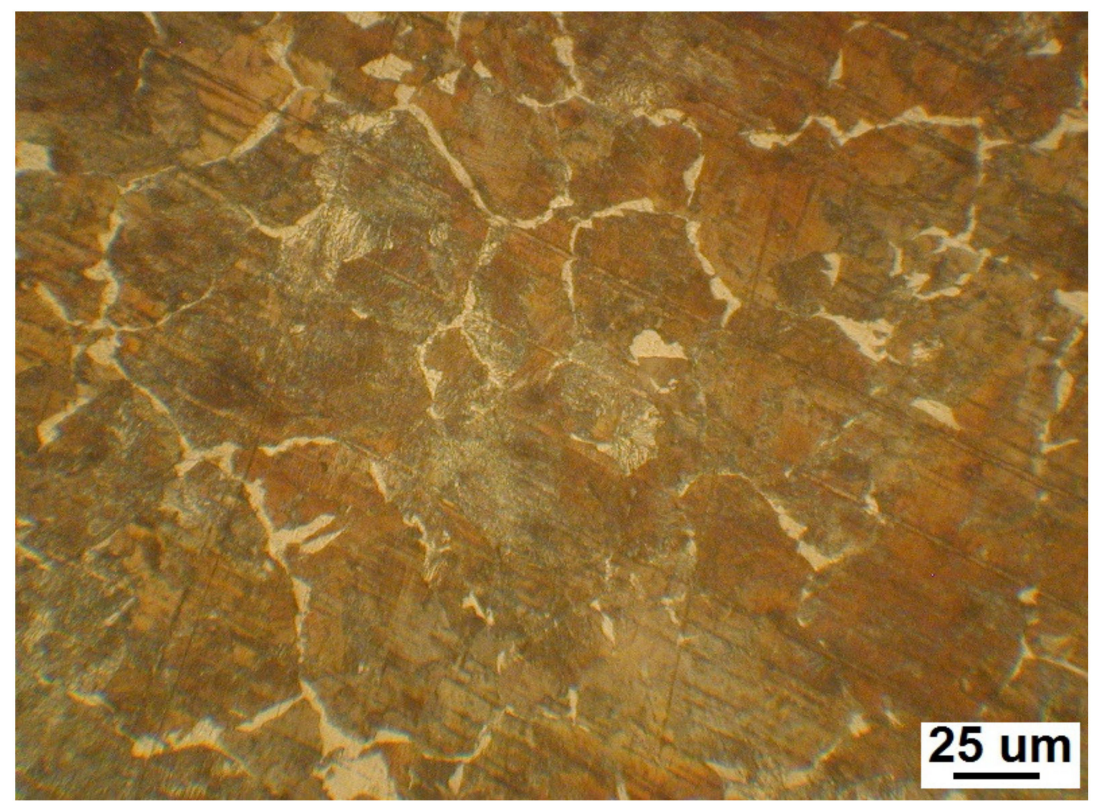

Figure 5. Sample No. 2, microstructure (nital).

\section{Discussion}

After considering the administrative and financial issues, the customer decided to continue to use heat-treated steel bolts STN 12061 (corresponds to EN ISO C60E). The supplier carried out an audit to ensure compliance with the parameters of bolts production according to regulations with emphasis on the heat treatment process. As a corrective measure, the measurement of the hardness of the supplied bolts was introduced. This is a simple operation that allows the operative elimination of bolts with hardness lower than declared, the hardness of each supplied bolt is measured.

In the month of June 2021, after the adoption of corrective measures, 13,899 sleepers were produced, of which 139 pieces were defective or an error occurred in the production process, which prevented its finalization. The results were used to construct the Pareto diagram, Figure 6.

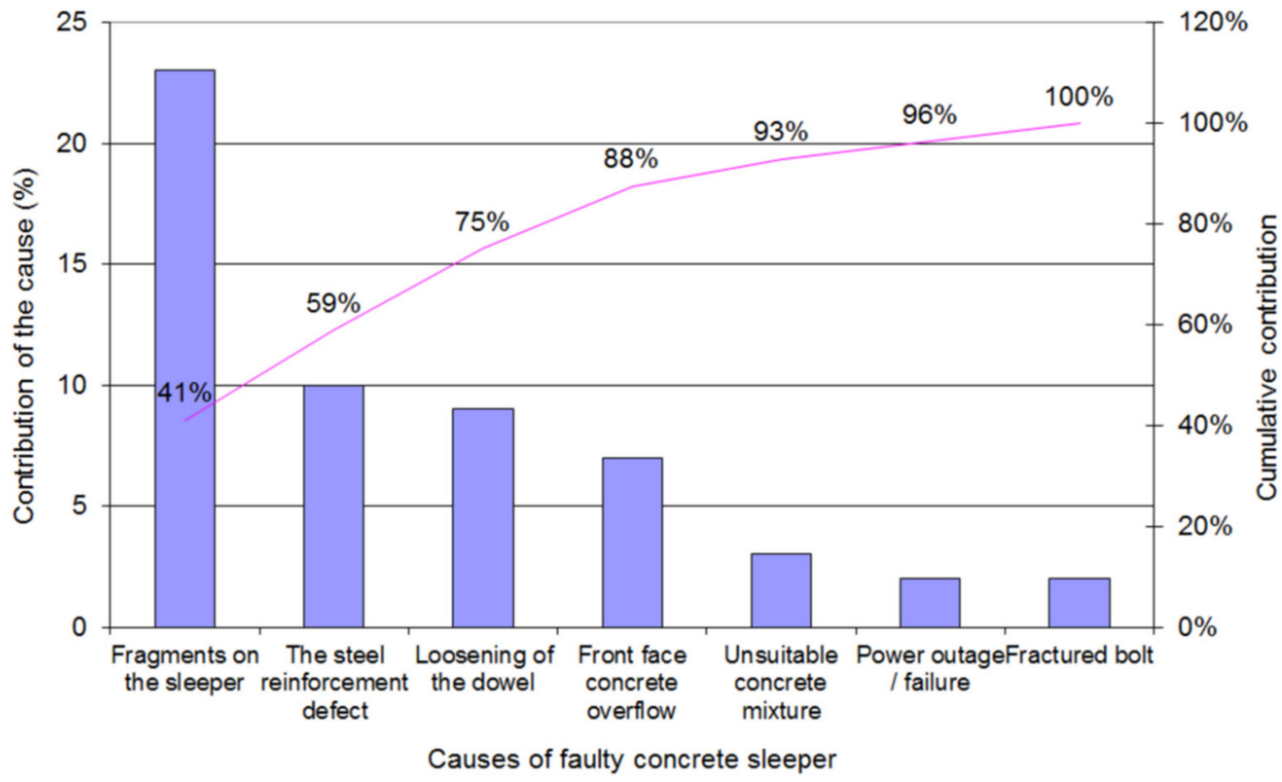

Figure 6. Pareto diagram after corrective action. 
It is clear from the diagram that the corrective action practically eliminated the most frequent cause of the nonconforming sleeper and reduced the frequency of occurrence of the related cause of reinforcement error by $5 \%$.

\section{Conclusions}

The production process of prestressed concrete sleepers was subjected to statistical analysis using selected simple quality management tools to identify possible causes of failure. The premature cracking of the bolts used for tightening the jaws holding the sleeper reinforcement wires was identified as the most significant cause. The unsatisfactory mechanical properties of the bolts were confirmed by hardness as well as microhardness measurements. The suspected use of improper material for the bolts was ruled out by chemical analysis. Microstructure analysis have shown that the short service life of the bolts was caused by insufficient or absent heat treatment. The insufficient toughness of the material led to premature bolt breakage, endangering operators by ejected fragments and resulted in loosening of the prestressed reinforcement. The adopted corrective action, operative measurement of the hardness of each bolt prior to its use, is not time or money consuming. The implemented measure practically eliminated the failures caused by this source of nonconformity. It has also increased workplace safety, alleviating operator stress as another potential cause of failure.

Author Contributions: Management and validation, writing and final review, Š.M. and J.P.; application of statistical, mathematical techniques, J.P. and P.B.; research and verification, M.Š.; development of methodology, P.P. and A.S.; data collection, P.B. and L.G. All authors have read and agreed to the published version of the manuscript.

Funding: This contribution is the result of the implementation of the following projects: KEGA No. 019TUKE-4/2020 "Application-oriented education in ISO 9001:2015 requirements implementation". This contribution is the result of the implementation of the following projects: KEGA No. 043TUKE4/2019 "Improving material engineering and integrated management systems study programs for Industry 4.0 ".

Institutional Review Board Statement: Not applicable.

Informed Consent Statement: Not applicable.

Data Availability Statement: Not applicable.

Conflicts of Interest: The authors declare no conflict of interest.

\section{References}

1. Camarillo, A.; Ríos, J.; Althoff, K.D. CBR and PLM Applied to Diagnosis and Technical Support during Problem Solving in the Continuous Improvement Process of Manufacturing Plants. Procedia Manuf. 2017, 13, 987-994. [CrossRef]

2. Mikos, W.L.; Ferreira, J.C.E.; Botura, P.E.A.; Freitas, L.S. A System for Distributed Sharing and Reuse of Design and Manufacturing Knowledge in the PFMEA Domain Using a Description Logics-Based Ontology. J. Manuf. Syst. 2011, 30, 133-143. [CrossRef]

3. ISO 9000; Quality Management System-Fundamentals and Vocabulary. International Organization for Standardization ISO: Geneva, Switzerland, 2015.

4. Vykydal, D.; Folta, M.; Nenadál, J. A Study of Quality Assessment in Higher Education within the Context of Sustainable Development: A Case Study from Czech Republic. Sustainability 2020, 12, 4769. [CrossRef]

5. European Parliament and European Council. Regulation (EU) No. 305/2011 Laying Down Harmonised Conditions for the Marketing of Construction Products and Repealing the Council Directive 89/106/EEC; European Parliament and European Council: Brussels, Belgium, 2011.

6. Teplická, K.; Hurná, S. New Approach of Costs of Quality According Their Trend of During Long Period in Industrial Enterprises in SMEs. Manag. Syst. Prod. Eng. 2021, 29, 20-26. [CrossRef]

7. Slimák, I.; Zgodavova, K. Focus on Succes. QIP J. 2011, 15, 1-4. [CrossRef]

8. Monkova, K.; Hric, S.; Knapčikova, L.; Vagaska, A.; Matiskova, D. Application of simulation for product quality en-hancement. In Proceedings of the International Conference on Informatics, Management Engineering and Industrial Ap-plication (IMEIA), Phuket, Thailand, 24-25 April 2016; pp. 216-220.

9. Lovska, A.; Fomin, O.; Ṕštěk, V.; Kučera, P. Dynamic load modelling within combined transport trains during transportation on a railway ferry. Appl. Sci. 2020, 10, 5710. [CrossRef] 
10. ASQ. ASQ Excellence through quality. 2020. Available online: https://asq.org/quality-resources/supplier-quality (accessed on 14 November 2021).

11. Foster, S.T. Towards an Understanding of Supply Chain Quality Management. J. Oper. Manag. 2008, 26, 461-467. [CrossRef]

12. ISO 9001; Quality Management System-Requirements. ISO: Geneva, Switzerland, 2015.

13. Onkal, D. (Ed.) Supply Chain Management_Pathways for Research and Practice; InTech: London, UK, 2011; ISBN 978-953-307-294-4.

14. Fan, J.; Ni, D.; Fang, X. Liability Cost Sharing, Product Quality Choice, and Coordination in Two-Echelon Supply Chains. Eur. J. Oper. Res. 2020, 284, 514-537. [CrossRef]

15. Bambura, R.; Šolc, M.; Dado, M.; Kotek, L. Implementation of Digital Twin for Engine Block Manufacturing Processes. Appl. Sci. 2020, 10, 6578. [CrossRef]

16. Nováková, R.; Šujanová, J.; Pauliková, A. Use of 8D Method in Nonconformity Resolution-A Case Study of Production of Spliced Veeners in Slovakia. Drv. Ind. 2017, 68, 249-260. [CrossRef]

17. Tomić, B.; Spasojević Brkić, V. Effective Root Cause Analysis and Corrective Action Process. JEMC 2011, 1, 5.

18. Meister, M.; Beßle, J.; Cviko, A.; Böing, T.; Metternich, J. Manufacturing Analytics for Problem-Solving Processes in Production. Procedia CIRP 2019, 81, 1-6. [CrossRef]

19. Kučera, P.; Píštěk, V. Automatic and Manual Differential Lock Control in a Truck-Cornering. In Proceedings of the 20th International Conference Transport Means, Juodkranté, Lithuania, 5-7 October 2016; pp. 98-101.

20. Markulik, S.; Nagyova, A.; Turisova, R.; Villinsky, T. Improving Quality in the Process of Hot Rolling of Steel Sheets. Appl. Sci. 2021, 11, 5451. [CrossRef]

21. Andersen, B.; Fagerhaug, T. Root Cause Analysis: Simplified Tools and Techniques, 2nd ed.; ASQ Quality Press: Milwaukee, WI, USA, 2006; ISBN 978-0-87389-692-4.

22. Burggräf, P.; Weißer, T.; Wagner, J. Data on the Current State of Problem Solving and Improvement during Physical Product Development within Complex (Manufacturing) Systems. Data Brief. 2019, 23, 103851. [CrossRef]

23. Pačaiová, H.; Sinay, J.; Turisová, R.; Hajduová, Z.; Markulik, Š. Measuring the Qualitative Factors on Copper Wire Surface. Measurement 2017, 109, 359-365. [CrossRef]

24. Nagyová, A.; Pačaiová, H.; Gobanová, A.; Turisová, R. An Empirical Study of Root-Cause Analysis in Automotive Supplier Organisation. Qual. Innov. Prosperity 2019, 23, 34-45. [CrossRef]

25. Zhao, L.H.; Xing, Q.K.; Wang, J.Y.; Li, S.L.; Zheng, S.L. Failure and root cause analysis of vehicle drive shaft. Eng. Fail. Analysis 2019, 99, 225-234. [CrossRef]

26. Ghatorha, K.S.; Sharma, R.; Singh, G. Application of root cause analysis to increase material removal rate for productivity improvement: A case study of the press manufacturing industry. Mater. Today Proc. 2020, 26, 1780-1783. [CrossRef]

27. Kumar, T.S.M.; Adaveesh, B. Application of "8D Methodology" for the Root Cause Analysis and Reduction of Valve Spring Rejection in a Valve Spring Manufacturing Company: A Case Study. Indian J. Sci. Technol. 2017, 10, 1-11. [CrossRef]

28. Mendez-Tores, B.A.; Cano-Olivos, P. Proposed Algorithm to Digitize the Root-Cause Analysis and 8Ds of the Automotive Industry; Verlag Springer International Publishing: Berlin/Heidelberg, Germany, 2021.

29. Hall, M.A. Root cause analysis: A tool for closer supply chain integration in construction. In Proceedings of the 17th Annual ARCOM Conference, University of Salford, Salford, UK, 5-7 September 2001; Association of Researchers in Construction Management: Salford, UK, 2021; Volume 1, pp. 929-938.

30. Al-Zwainy, F.M.S.; Mohammed, I.A.; Varouqa, I.F. Diagnosing the Causes of Failure in the Construction Sector Using Root Cause Analysis Technique. J. Eng. 2018, 2018, 1-12. [CrossRef]

31. Nidal, A. Diagnosing the Causes of Poor Quality Management in Iraqi Construction Projects Using Technique of Root Cause Analysis. IOP Conf. Ser. Mater. Sci. Eng. 2021, 1076, 10-1088.

32. EN 13230-1; Railway Applications-Track-Concrete Sleepers and Bearers-General Requirements. European Committee for Standardization CEN: Brussels, Belgium, 2016.

33. EN 13230-2; Railway Applications-Track-Concrete Sleepers and Bearers- Prestressed Monoblock Sleepers. European Committee for Standardization CEN: Brussels, Belgium, 2016.

34. PrEN 10138; Prestressing Steels-Wire. European Committee for Standardization CEN: Brussels, Belgium, 2000.

35. EN 10080; Steel for the Reinforcement of Concrete-Weldable reinforcing steel-General. European Committee for Standardization CEN: Brussels, Belgium, 2005.

36. EN 206; Concrete-Specification, Performance, Production and Conformity. European Committee for Standardization CEN: Brussels, Belgium, 2002.

37. STN 73 1322; Determination of Frost Resistance of Concrete. Slovak Office of Standards, Metrology and Testing, Slovak technical standard STN: Bratislava, Slovakia, 2016.

38. EN 12620+A1; Aggregates for Concrete. European Committee for Standardization CEN: Brussels, Belgium, 2002.

39. Girmanová, L.; Mikloš, V.; Palfy, P.; Petrík, J.; Sütőová, A.; Šolc, M. Nástroje a Metódy Manažérstva Kvality; ELFA, s.r.o.: Košice, Slovakia, 2009; (In Slovak). ISBN 978-80-553-0144-0.

40. Kučera, P.; Píštěk, V.; Prokop, A.; Řehák, K. Measurement of the powertrain torque. In Proceedings of the Engineering Mechanics, Svratka, Czech Republic, 14-17 May 2018; pp. 449-452.

41. Teplická, K.; Khouri, S.; Beer, M.; Rybárová, J. Evaluation of the Performance of Mining Processes after the Strategic Innovation for Sustainable Development. Processes 2021, 9, 1374. [CrossRef] 
42. Bunkley, N. “Joseph Juran, 103, Pioneer in Quality Control, Dies". The New York Times. Available online: https: / www.nytimes. $\mathrm{com} / 2008 / 03 / 03 /$ business / 03juran.html (accessed on 13 November 2021).

43. ISO 6506-2; Metallic Materials-Brinell Hardness test-Verification and Calibration of Testing Machines. 3rd ed. International Organization for Standardization ISO: Geneva, Switzerland, 2017.

44. ISO 6506-1; Metallic Materials-Brinell Hardness test-Test Method. 3rd ed. International Organization for Standardization ISO: Geneva, Switzerland, 2014.

45. ISO 6507-2; Metallic Materials-Vickers Hardness Test-Verification and Calibration of Testing Machines. 3rd ed. International Organization for Standardization ISO: Geneva, Switzerland, 2018.

46. ISO 6507-1; Metallic Materials-Vickers Hardness Test-Test Method. 3rd ed. International Organization for Standardization ISO: Geneva, Switzerland, 2018. 